\title{
Assessment of Physicochemical Characteristics of Selected Borehole Waters in Oke-Oyi Community, Ilorin East Local Government Area, Kwara State
}

\section{*11SMAILA, O. SAHEED: ${ }^{1}$ SAMSUDEEN, O. AZEEZ; ${ }^{1}$ YUSUF, O. AYIPO; ${ }^{1}$ USAKA C. GUNU}

\author{
${ }^{I}$ Department of Chemical, Geological and Physical Sciences, Kwara State University, Malete, Nigeria \\ aismailolalekan2@gmail.com; ${ }^{b}$ samsudeen.azeez@kwasu.edu.ng; ${ }^{c} y u s u f . a y i p o @ k w a s u . e d u . n g ;{ }^{d}$ khristof8@yahoo.com \\ Corresponding author: ismailolalekan2@gmail.com
}

\begin{abstract}
The physicochemical parameters of seven different borehole waters in Oke-Oyi, Ilorin East Local Government Area, Kwara State, Nigeria were assessed to determine it suitability for human consumption. The parameters examined include temperature $\left(28-29^{\circ} \mathrm{C}\right)$, conductivity $(414-1603 \mu \mathrm{s} / \mathrm{cm}), \mathrm{pH}(5.71-6.57)$, total hardness $(20.2-67.3 \mathrm{mg} / \mathrm{L})$. The concentrations of heavy metals determined are $\mathrm{Zn}(0.010-0.022 \mathrm{mg} / \mathrm{L}), \mathrm{Fe}(0.002-$ $0.120 \mathrm{mg} / \mathrm{L}), \mathrm{Cr}(0.075-0.12 \mathrm{mg} / \mathrm{L}), \mathrm{Cu}\left(3 \times 10^{-4}-2 \times 10^{-3} \mathrm{mg} / \mathrm{L}\right), \mathrm{Co}(0.01-0.26 \mathrm{mg} / \mathrm{L})$ and $\mathrm{Mn}(0.082-0.94 \mathrm{mg} / \mathrm{L})$ There was no lead detected in two of the borehole water samples while those detected have low concentration range 1 $\mathrm{x} 10^{-5}-6 \times 10^{-5}$. The results of physicochemical parameters obtained are within World Health Organisation (WHO) limits except for the $\mathrm{pH}$ that is slightly lower and the conductivity of OKY 1 that is slightly higher. (C) JASEM https://dx.doi.org/10.4314/jasem.v21i6.22
\end{abstract}

Keywords: Borehole water, physicochemical parameters, Heavy metals, Community, Quality

Water covers about $75 \%$ of the earth surface. It is found as surface water in streams, rivers, etc, and as ground water when locks up in the rock (Chandra $e t$ $a l ., 2012)$. Water is made of two elements, hydrogen and oxygen and is sometimes called "universal solvent" as it can dissolve many substances. Water is essential for many biochemical reactions in living cells. It's also important in many industrial and manufacturing activities (Franks, 2000). Therefore, reliable water source is an essential material for establishing a stable and safe community (Waziri et al., 2009; Kolo and Baba, 2004).

It's a known fact that human health and survival is connected with the availability of clean water for drinking and purposes. Groundwater is the water present beneath the earth's surface and also a fresh water source due to its lower tendency to be polluted in comparison with surface water and its large storage capacity (Idoko 2010; Abii and Nwabienvanne, 2007). It was estimated that about one third of the world's population uses groundwater for drinking and nowadays more than half of the world's population depends on groundwater for survival (Mohrir et al., 2009). The anthropogenic disturbances have influence on the quality of groundwater. Groundwater quality degradation arises from variation of some quality parameters through the introduction or removal of certain substances (Ramesh et al., 2001).

Trace metals are natural components of the earth crust and some are required in minute quantities for metabolism in organisms (e.g. arsenic, copper, iron, etc.) (Ward, 1995). The presence of toxic metals such as $\mathrm{Pb}$ and $\mathrm{Cd}$ in the environment has been of environmental concern. This is mainly due to their health implications as some are carcinogenic and non-essential to human body (Tyler, 1981). Trace metals are common environmental pollutants with sources mainly from weathering of rocks (Merian, 1991). The concentration level of these metals in the environment has increased rapidly in the past few years as a result of human activities such as discharge of industrial and domestic wastes (Prater, 1975). Therefore, metal pollution comes from both natural and anthropogenic sources (Moore and Ramamoorthy, 1984).

This study is aimed at determining the physicochemical properties of selected borehole waters in Oke-Oyi Community, Ilorin East Local Government Area of Kwara State in order to ascertain the portability of the water and its quality for human use.

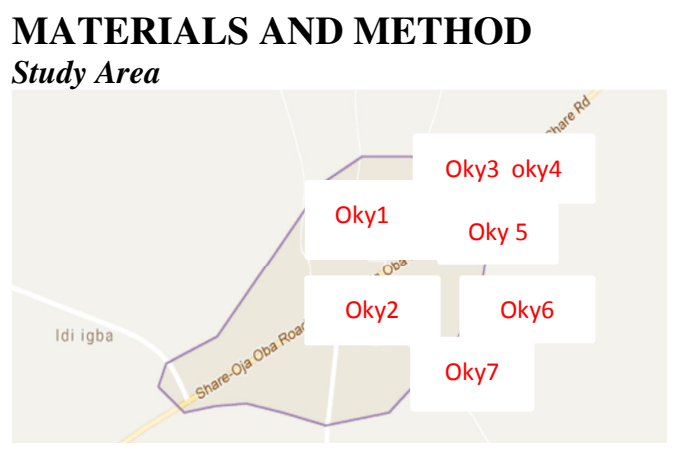

This study was carried out in Oke-Oyi Community, Ilorin East Local Government Area of Kwara State. This community is located in Kwara State, Nigeria at longitude $8^{\circ} 35^{\prime} 0$ " North and Latitude $4^{\circ} 43$ '0" East and is characterized by a tropical climate with two distinct seasons; wet and dry seasons. Monthly temperature ranges from $20{ }^{\circ} \mathrm{C}$ to $34{ }^{\circ} \mathrm{C}$. Water samples were collected at seven different locations of Boreholes situated at Oke Oyi community. These 
locations are denoted with Oky 1, Oky 2, Oky 3, Oky 4, Oky 5, Oky 6 and Oky7 respectively.

Sample Collection and Preparation: The water samples were collected into polythene bottles prewashed with detergent, diluted $\mathrm{HNO}_{3}$ and distilled de-ionised water. Samples for heavy metal analysis were preserved by adding few drops of 1 Molar $\mathrm{HNO}_{3}$ (Manilla and Frank, 2009). The samples were labeled and quickly transported to the laboratory in a cooler of ice for physicochemical analysis.

Physicochemical Analysis: Determination of $p H$ : The $\mathrm{pH}$ of the water samples was carried out in-situ using digital $\mathrm{pH}$ meter standardized with buffer 4, 7 and 9 respectively. The $\mathrm{pH}$ meter's electrode was dipped into $100 \mathrm{~cm}^{3}$ of a water sample and the reading was recorded (APHA, 1999). The procedure was repeated for the other samples.

Temperature measurement: The temperature of the water was taken immediately the sample was collected on site. Mercury in glass thermometer was dipped into $100 \mathrm{~mL}$ of water sample and was left for few minutes after which the temperature was recorded (APHA, 1999). The procedure was repeated for other samples.

Determination of conductivity: This was done using a conductivity meter. The meter's electrode was immersed into $20 \mathrm{~mL}$ of the water samples until a stable reading was recorded.

Determination of total hardness of water: $2 \mathrm{~mL}$ of buffer 10 was added to $50 \mathrm{~cm}^{3}$ of the water sample in a conical flask and stirred for homogeneity. 3 drops of eriochrome black $\mathrm{T}$ indicator was added and a pink colouration was observed. The sample was then titrated against $0.1 \mathrm{M}$ EDTA until a blue colouration was observed. The titre value obtained was multiplied with 44.892 as the approved conversion factor and the total hardness was expressed in $\mathrm{mg} / \mathrm{L}$. The same procedure was repeated for the other six samples (Adelunle et al., 2007).

Heavy metal determination: Atomic absorption spectrometry was carried out using Alpha 4 Atomic
Absorption Spectrometer (PM 8251 single pen recorder) to determine the concentration of heavy metals present in the water samples. $100 \mathrm{~mL}$ of each sample was heated and $10 \mathrm{~mL}$ of $1 \mathrm{M}$ nitric acid was added while the heating continues until the volume is reduced to $10 \mathrm{~mL}$. Thereafter, the solution was filtered into a clean beaker and made up to $100 \mathrm{~mL}$ with distilled water in a volumetric flask and subsequently packed into a sample container (plastic) for AAS.

\section{RESULTS AND DISCUSSION}

The temperature of all the borehole waters collected ranged between 28 and $29^{\circ} \mathrm{C}$ (Table 1). These values are similar to those obtained by Ukpong and Okon, (2013) and Chukwu (2008) and are within the permissible limit of WHO for natural ground water that could be used for human consumption.

The $\mathrm{pH}$ of all the water samples (Table1) is below the WHO limit for drinkable water (Ukpong and Okon 2013), except that of OKY 1 which is within the WHO limit. The obtained $\mathrm{pH}$ values show that the borehole waters are slightly acidic and could be due to underground pollution caused by agricultural practices in the area.

The result of the conductivity (Table 1) shows that the conductivities of all the water samples are within permissible limit of WHO except for OKY 1 (Istifanus et al., 2013; Olalekan et al., 2015). However, it is observed that the mobility of ions in solution is slightly high in all the water samples. This is not surprising as the flow of water would be proportional to the concentration of the hydrogen ions in the water.

The result of the hardness test (Table 1) for all the water samples shows that all the borehole waters are soft according to WHO limit for drinkable water.

The result of heavy metals $\mathrm{Pb}, \mathrm{Zn}, \mathrm{Fe}, \mathrm{Cr}, \mathrm{Cu}, \mathrm{Co}$ and Mn (Table 2) assessed on all the water samples reveal that heavy metal concentration determined are within the WHO permissible limit for potable water.

Table1: Physicochemical Parameters of the Water Sample

\begin{tabular}{lllll}
\hline SAMPLE & $\begin{array}{l}\text { Temperature } \\
\left({ }^{\circ} \mathrm{C}\right)\end{array}$ & pH VALUE & $\begin{array}{l}\text { Conductivity } \\
(\mu \mathrm{S} / \mathrm{CM})\end{array}$ & $\begin{array}{l}\text { Total Hardness } \\
(\mathrm{mg} / \mathrm{L})\end{array}$ \\
\hline OKY 1 & 29 & 6.57 & 1603 & 67.3 \\
OKY 2 & 29 & 5.96 & 838 & 38.1 \\
OKY 3 & 28 & 5.90 & 595 & 20.2 \\
OKY 4 & 29 & 5.83 & 1274 & 38.1 \\
OKY 5 & 28 & 5.79 & 775 & 35.9 \\
OKY 6 & 28 & 5.71 & 414 & 29.2 \\
OKY 7 & 29 & 5.97 & 1156 & 35.9 \\
\hline
\end{tabular}


Table2: Heavy Metal Concentration of the Water samples

\begin{tabular}{llllllll}
\hline SAMPLE & $\begin{array}{l}\text { LEAD } \\
(\mathrm{mg} / \mathrm{L})\end{array}$ & $\begin{array}{l}\text { ZINC } \\
(\mathrm{mg} / \mathrm{L})\end{array}$ & $\begin{array}{l}\text { IRON } \\
(\mathrm{mg} / \mathrm{L})\end{array}$ & $\begin{array}{l}\text { CHROMIUM } \\
(\mathrm{mg} / \mathrm{L})\end{array}$ & $\begin{array}{l}\text { COPPER } \\
(\mathrm{mg} / \mathrm{L})\end{array}$ & $\begin{array}{l}\text { COBALT } \\
(\mathrm{mg} / \mathrm{L})\end{array}$ & $\begin{array}{l}\text { MAGNANESE } \\
(\mathrm{mg} / \mathrm{L})\end{array}$ \\
\hline OKY 1 & 0.00001 & 0.020 & 0.020 & 0.075 & 0.002 & 0.01 & 0.082 \\
OKY 2 & 0.00004 & 0.010 & 0.003 & 0.075 & 0.0003 & 0.05 & 0.094 \\
OKY 3 & NIL & 0.016 & 0.002 & 0.10 & 0.0003 & 0.01 & 0.14 \\
OKY 4 & 0.00001 & 0.020 & 0.003 & 0.10 & 0.0003 & 0.12 & 0.12 \\
OKY 5 & 0.00002 & 0.020 & 0.003 & 0.12 & 0.0003 & 0.25 & 0.12 \\
OKY 6 & 0.00006 & 0.012 & 0.120 & 0.10 & 0.0004 & 0.26 & 0.14 \\
OKY 7 & NIL & 0.022 & 0.120 & 0.10 & 0.0003 & 0.26 & 0.94 \\
\hline
\end{tabular}

Conclusion: The assessment of physicochemical parameters reveals that all the water samples are not hard water. The study also reveals that the heavy metal concentrations determined are within the permissible limit of WHO for human consumption. The $\mathrm{pH}$ of the water samples are slightly lower than the WHO standard and could be due to underground pollution caused by agricultural activities in the area. The borehole waters only need minor treatment such as addition of $\mathrm{Na}_{2} \mathrm{CO}_{3} \cdot 10 \mathrm{H}_{2} \mathrm{O}$ for stabilizing the $\mathrm{pH}$, and therefore suitable for human consumption.

\section{REFERENCES}

Abii, T.A., and Nwabienvanne E.U. (2007) Investigation on Trace Metals Content of Some Selected Boreholes Waters Around Umuahia Metropolis. Research Journal of Applied Science 2(4): 494-496

Adelunle, I.M.M., Adetunji, M.T., Gbadebo, A.M., and Banjoko, O.B. (2007) Assessment of groundwater quality in a typical rural settlement in south west Nigeria. Int. J. Res. Pub. Health 4: $307-315$

American Public Health Association, APHA (1999), Standard Methods foe Examination of Water and waste water 20th Ed. pp. 5

Chandra, S.; Singh, A.; Tomar, P.K. (2012) Assessment of water quality values in Porur Lake Chennai, Hussain Sagar Hyderabad and Vihar Lake Mumbai, India. Chem. Sci. Trans. 1: $508-515$

Chukwu, G.U. (2008) Water quality Assessment of Boreholes in Umuahia South Local Government Area of Abia State. The Pacific Journal of Science and Technology 9(2):592-594

Franks, F. (2000), "Water: A Matrix of Life", 2nd Edition, RSC Paperback, UK, pp. 225.

Idoko, O.M. (2010) Seasonal Variation in Iron in Rural Groundwater of Benue State, Middle Belt, Nigeria. Pakistan Journal of Nutrition 9(9): 892-895

Istifanus, Y. Chindo, E.K., Ishaku, Z. and Ephraim, D.A. (2013) Physicochemical Analysis of Ground Water of Selected Areas of Dass and Ganjuwa Local Government Areas, Bauchi State, Nigeria. World Journal of Analytical Chemistry 1, no. 4 (2013): 73-79. doi: 10.12691/wjac-1-4-6.

Kolo, B.G. and Baba S. (2004) Analysis of some water samples from Hong local Government area of Adamawa state, Nigeria. Borno Journal of Geology 3(4-5): 54-59
Mannila, P.M. and Frank, O.M. (2009) Lakes of the Niger Delta Flood Plain I. Chemical Characteristics of five lakes (Akipe, Egbedidi, Esiribi, Aboh and Egbinya) in Bayelsa State, Nigeria. Journal of Chem. Soc. Nig. 34 (2): 44.

Merian, E. (ed.) 1991. Metals and their Compounds in the Environment: Occurrence, Analysis and Biological Relevance. UCH Weinheim: New York, NY. -and- BaselCambridge, O’Neil pp. 1993

Mohrir, A., Ramteke. D.S., Moghe, C.A., Wate, S.R. and Sarin, R. (2002). Surface and ground water quality assessment in Bina region. Indian J. Environ. Prot. 22(9): 961-969.

Moore, J.W. and Ramamoorthy, S. (1984) Heavy Metal in Natural Waters. Applied Monitoring and Impact Assessment. Springer-Veriag: New York, NY. 59(4): 493

Olalekan, A., Abubakar, B. and Abdul-Mumini, K. (2015) Physicochemical characteristics of borehole water quality in Gassol Taraba State, Nigeria. African Journal of Environmental Science and Technology 9(2) : 143-154

Prater, B.E. (1975) The Metal Content and Characteristics of Steelwork Effluents Discharging to the Tees Estuary. Water Pollution Control 74:63-78

Ramesh, R., Subramanian, V. and Ramanathan, A.L. (2001) Point and Non-point sources of Groundwater Pollution: Case Studies along the East Coast of India, Proceedings of the International Workshop on Ecohydrology, Capital Publishing Company, New Delhi, India, pp. 107.

Tyler, T.G. (1981) "Heavy Metals in Soil Biology and Biochemistry". In: Paul, E.A. and Ladd, J.N. (eds.). Soil Biochemistry. Marcel Dekker: New York, NY. 33 pp - and Borgmann, U. 1983. "Metal Speciation and Toxicity of Free Metal Ions to Aquatic Biota”. In: Nriagu J.O. (ed.) Aquatic Toxicity, Advances in Environmental Science and Technology. Vol. 13. John Wiley \& Sons: New York, NY. 47-73

Ukpong, E.C. and Okon B.B. (2013) Comparative Analysis of Public and Private Borehole Water Supply Sources in Uruan Local Government Area of Akwa Ibom State. International Journal of Applied Science and Technology 3 (1): 2013.

Ward, N.I. (1995) “Trace Elements". In: Fifield, F.W. and Haines, P.J. (eds.). Environmental Analytical Chemistry. Blackie Academic and Professional, Chapman and Hall: London, UK.

Waziri, M., Ogugbuaja, V.O. and Dimari, G.A. (2009) Heavy metal concentrations in surface and groundwater samples from Gashua and Nguru Areas of Yobe State, Nigeria. Integrated Journal of Science and Engineering 8(1): 58-63 